\title{
Benign Infratentorial Neoplasm
}

National Cancer Institute

\section{Source}

National Cancer Institute. Benign Infratentorial Neoplasm. NCI Thesaurus. Code C4965.

A benign neoplasm that occurs in the infratentorial region. 